\title{
Deed Of Roya Consent Which Made By Notary In Roya Mortage Rights Caused The Loss Of Certificate Mortage Rights In The City Of Pekalongan
}

\author{
Indah Nailal Muna ${ }^{1}$, Hanung Hendratmoko ${ }^{2}$ and Anis Mashdurohatun ${ }^{3}$ \\ Abstract. The purpose of this study was to: 1) To determine the debtor to Roya to BPN \\ 2) To know the challenges and solutions faced by the debtor to Roya missing \\ Encumbrance certificate 3 ) to determine the position of the missing Encumbrance \\ certificate. The research method in this study, using socio-juridical to obtain data from \\ the primary data. In a research specification is a descriptive analysis of this data is by \\ using the applicable laws. \\ Based on the results of data analysis concluded that: 1) The process of the debtor to \\ Roya namely by applying Roya Land Office and bring equipment such as certificates \\ and certificate concern Properties Roya who made by notary. 2) The obstacles faced \\ by the debtor that is, if not made deed Roya consent by a notary then the debtor can \\ not perform Roya or deletion in Encumbrance, while the solution is to bring the letter \\ of loss from the police and then come before the notary to be made a deed of Roya \\ consent by a notary to replace certificates mortgages missing. 3) Position the deed of \\ Roya consent can not be equated with a certificate of mortgages have executorial \\ power because it is not regulated in the legislation or firm rule. The deed of Roya \\ consent is a requirement to carry out orderly land administration. In this case means \\ that the position of Roya consent deed made by the notary is a custom in notarial \\ practice. \\ Keywords: Deed of Consent Roya; Notary; Certificate of Mortage Right.
}

\section{Introduction}

Indonesia as a developing country characterized by the presence of national sustainable development program. Economic development as part of national development is an effort to realize the people's welfare fair and prosperous, based on Pancasila and the Constitution of 1945.

Many entrepreneurs are confronted with the problem of lack of capital stock, and under such circumstances, these entrepreneurs will require the other party to provide a loan or credit. This is where the other party is reliable for giving credit where it is one of the functions of banks are very supportive of economic growth.

Presence of collateral in the form of a guarantee is considered very important although it can not be said absolutely in lending from financial institutions to the public. In everyday banking practices, the mortgage can be tied to pledge security institutions based on the Civil Code and fiduciary insurance agency based under Law 42 of 1999 on Fiduciary, if such is an object to move, or to institute Encumbrance by Act No.4 1996 on mortgage of land along with different things connected with the land, if the collateral is in the form of land or buildings. ${ }^{4}$

\footnotetext{
${ }^{1}$ Student Master of Notary Program, Faculty of Law, Sultan Agung Islamic University, email indah.nailal@gmail.com

${ }^{2}$ Student of Master of Law Program, Faculty of Law, Universitas Islam Sultan Agung email hanungh78@gmail.com

${ }^{3}$ Lecturer, Faculty of Law, Sultan Agung Islamic University

${ }^{4}$ Anis Masdurrohatun,2016, Rekonstruksi Parate Eksekusi Hak Tanggungan Atas Tanah Yang Berkeadilan, Unissula Press.
} 
Practice as creditor banks in providing credit facilities, ask the debtor to submit a guarantee based on the requirements previously been agreed between the bank as lender and the borrower as the borrower. Guarantee is a guarantee that the debtor submitted to the bank in order to award credit facility and an element of judgment made by the bank before giving credit to those who need it. According to the bank, guarantees the most secure and appropriate to the credited amount issued is the land, because the land certain limits regarded as a relatively safe collateral objects, in the sense that if the land pledged no problem. Soil is a guarantee of a highly profitable for the bank, as well as higher selling prices.

Land as collateral to obtain credit, can not be separated with the Law, which regulates on the ground. With the enactment of BAL on September 24, 1960, the guarantee of land called the "Mortgage".

In essence, Encumbrance is a follow-up (Accessoir) in the principal agreement, the agreement raises the legal relationship of debts. Thus, the presence, the transition and the abolishment of the security rights dependent on the repayment of the secured debt.

In Act No. 5 of 1960 on Basic Regulation of Agrarian (BAL) has been mentioned about the existence of the institution of mortgage as collateral or credit., Which according to Article 25, 33, and 39 BAL revealed that the right, leasehold and Right to buildings can be used as debt burdened Mortgage. Binding of credit guarantees with mortgage is done when a customer or debtors who obtain credit from banks, making immovable goods in the form of land (land rights) following or not following objects not related to the land as collateral without the debtor deliver goods the guarantee physically to creditors (banks). Thus the right of ownership of the land remains with the original owner or grantor security rights, while banks had only Encumbrance who gives the right to obtain repayment on its accounts receivable in advance of other creditors. Implementation of this agreement is a series of a principal agreement is a credit agreement, therefore the implementation of the new bail bonding can be done after the credit of agreement done.

Roya deed of consent is one of the authentic deed made a notary at the request of the bank, which contains a statement by the bank that the Certificate of Mortgage borrowers who are in power have been lost, which the Certificate of Mortgage is a condition for debtors who have paid off their debts to Roya. Roya consent deed existence is based on the habit in practice because of the legislation related to the security rights has not been set.

Deed Roya consent although not specifically regulated in regulations, notaries authorized to make this deed under Article 15 paragraph (1) UUJN where the notary is authorized to make the authentic act on all deeds, agreements, and provisions required by legislation and desired by stakeholders to be stated in an authentic deed.

From the description of the background of the above, the formulation of a problem that can be submitted are as follows: What is the process for Roya debtor to the National Land Agency to object Mortgage? How challenges and solutions faced by the debtor to Roya against Encumbrance certificate is missing? and What are the capacities of the Encumbrance certificate is missing?

\section{Research methods}

This study using sociological juridical approach, because according to the author's purpose that this study is directly related to people or more leads to the fact what was in the field. This research is descriptive analysis to provide the data as accurately as 
Volume 7 Issue 1, March 2020

Nationally Accredited Journal,

Decree No. B/4130/E5/E5.2.1/2019

possible about a social phenomenon or phenomena that occur in the life of the community by simply exposing the facts systematically. The data collection method to the study of literature and field study. Data analysis technique literature study and field study after a complete and check its validity will be analyzed qualitatively.

\section{Results and Discussion}

\subsection{The Process Of Debtor To Roya In The National Land Agency Of The Places Encumbrance}

The elucidation of Article 22 paragraph 1 of Act No. 24 of 1996, noted that the writeoff or Roya encumbrance records do for the sake of administrative order and have no legal effect on the mortgages in question has been removed. Remove security rights for the events referred to in Article 18 of Act No. 4 of 1996.

Encumbrance is consequences of accesoir nature of Encumbrance namely the Mortgage depending on their claims guaranteed repayment. If the receivables were removed for redemption or other causes by itself the security rights was clear too. Encumbrance is a guarantee of debt assignment is for the benefit of creditors. Therefore, it is the authority for creditors to remove Mortgage has, this situation is different from the giver Encumbrance which could not liberate this Mortgage.

Mortgage abolishment for cleaning Encumbrance be determined by the ranking by the Chairman of the Court is concerned with the provision of Article 19 paragraph (1) UUHT. According to this provision, the buyer Mortgage object either in a public tender or on the orders of Chairman of the Court as well as the sale and purchase voluntary, may request Mortgage holders who exceed the purchase price.

Abolishment of tenure, which became the object of mortgage can result in the abolition of the Mortgage. Of land rights among others to remove because of the matters referred to in Article 27, Article 34, da Article 40 BAL (Basic Agrarian Law) or other legislation. In this case remove security rights for non-fulfillment of the objective validity of the terms of the agreement, particularly relating to their mortage for a particular objective, one of which includes the existence of plots of land as collateral.

\subsection{Facing Challenges And Solutions For Roya Mortgage Debtors To The National Land Agency To Object Encumbrance}

Losses for creditors is that whenever there is a bad credit then the creditor difficulties to apply for an auction of objects of mortgage due encumbrance certificate can not be attached to the application for the auction to KPKNL (State Property Office and Auction). As for debtors is difficult to make Roya Encumbrance Land Office.

Solutions to overcome obstacles in the role of the notary in the deed Roya consent because abolishment of debt in the perspective of legal certainty are as follows:

- Timeliness in resolving Roya Encumbrance

The application of these sanctions is not found in practice that exceeds the Roya implementation period of 7 (seven) days due to errors or omissions Officer.

- Roya cost certainty Encumbrance

To overcome this problem, then you should charge the payment was made by the applicant by way of a deposit in a bank deposit and proof of this is a requirement for making Roya land certificates. Instruction of the State Minister of Agrarian 
Affairs / Head of National Land Agency Number 2 of 1994 dated March 18, 1994 on the prohibition of the reception power.

- Roya completeness requirements must be met

To overcome the problem of the issue of completing the requirements of this Roya then that must be taken are:

- There must be a letter of introduction from creditors Roya

Introduction Roya can re-request the help of the bank as a creditor to publish it.

- Must attach a certificate of land rights

If the land certificate, which is the object of mortgage is missing, this can be resolved by issuing a replacement certificate. Replacement certificate issuance process refers to the provisions of the Government Regulation No. 24 of 1997 on Land Registration

- Must attach a certificate Encumbrance

Encumbrance certificate if for some reason are not returned to the Land Office, then this is recorded in the land book Encumbrance (Article 22 paragraph 3 of Act No. 4 of 1996 on Mortgage Law). This provision provides convenience if the certificate Encumbrance can not be restored, then the other statements either to be made Roya consent made before a notary and submit to the Land Office and pleaded Encumbrance so that Roya the land book and certificate of land due to debts already written off its causes which should explained whether for paid or due to something else.

The loss of security rights certificate in essence can be detrimental to both parties both creditors and debtors. Losses for creditors is that whenever there is a bad credit then the creditor difficulties to apply for an auction of objects of mortgage due encumbrance certificate can not be attached to the application for the auction to KPKNL (State Property Office and Auction). As for debtors is difficult to make Roya Encumbrance Land Office.

\subsection{Position against the deed of Roya consent Mortgage to the loss of the certificate of mortgage}

According to Act No. 4 of 1996 on Mortgage, Mortgage is a security interest that is charged to the right to land. If you want to borrow money from banks or other financial institutions then handed over land rights certificates as collateral. The process should applied when applying for these loans is by signing the Credit Agreement (PK) followed by the signing of the Deed Granting Mortgage (APHT) before the officials, the PPAT.

Laws regarding lending a modern secured with mortgage set up an appointment and relationship accounts payable particular between the creditor and the debtor that includes the rights of creditors to sell the auction of assets of particular between the creditor and the debtor that includes the rights of creditors to sell the auction of the assets of certain designated specifically as collateral, as well as taking repayment of its receivable from the sale of proficiency level, if the debtor break a promise. In taking this repayment the lender has the right precede than other creditors (droit de preference). Given the importance of the birth of encumbrance for the creditor, in article 13 paragraph (4) UUHT emphasized that there must be a determination with certainty about the date the encumbrance of the land book is concerned. That date is the date the seventh day after the letters necessary for receipt of the complete application. If the seventh day falls on a holiday, the land book is dated the next day. 
Encumbrance Certificate enactment strength, there are two (2) types of proof properties, namely:

- The certificate is evidence of strong rights.

- Certificate as proof is absolute.

Unlike the case with land rights certificate, if the certificate is lost or damaged, then the certificate can be issued a replacement for encumbrance certificates are not issued certificate replacement. And therefore to replace the certificate of mortgage made by deed permission or Roya consent Roya security rights as a precondition for Roya to remove the encumbrance for the abolition of the debt (keel).

Roya consent Deed made by notary it is only a substitute for encumbrance certificates are lost in the process Roya not for execution, so that its position can not be equated with a certificate of mortgages have executorial power because it is not regulated in the legislation or firm rule. The deed of Roya consent is a requirement to carry out orderly land administration. In this case means that the position of Roya consent deed made by the notary is a custom in notarial practice. In the study of customary law can be said to be one of legal sources. ${ }^{5}$

\section{Closing}

\subsection{Conclusion}

- Procedure The Debtors To Make Roya To The Land Office; Article 13 of Law Mortgage, Mortgage Provision shall be registered at the Land Office not later than seven (7) working days after the signing of the Deed Granting Mortgage concerned and other necessary warkah to the Land Office. If the credit process between debtors and creditors (Bank) has been completed, the bank issued a Certificate of paid and Roya letter addressed to the Head of the Land Office that contains a request that the record Mortgage removed immediately. Roya means the removal or deletion, Roya Mortgage provided for in Article 22 of Act No. 4 of 1996 on Mortgage. And if to occur Encumbrance certificate is missing,

- Challenges And Solutions Faced By The Debtor To Roya Against Mortgages Lost Certificate; Obstacles faced by the debtor of loss Certificate of Mortgage highly injurious to themselves (the debtor) as the owner of the certificate Right to lands that are not tied up collateral for a debt, because despite the establishment of the settlement but has not done Roya (deletion), the owner of the certificate land rights can not take legal actions either the transfer of rights or imposition. The loss of security rights certificate in essence can be detrimental to both parties both creditors and debtors. Losses for creditors is that whenever there is a bad credit then the creditor difficulties to apply for an auction of objects of mortgage due encumbrance certificate can not be attached to the application for the auction to KPKNL (State Property Office and Auction).

Solutions to overcome obstacles in the role of the notary in the deed Roya consent because abolishment of debt in the perspective of legal certainty is Timeliness in resolving Roya Mortgage. The application of these sanctions is not found in practice that exceeds the Roya implementation period of 7 (seven) days due to errors or omissions Officer. It also should be regulated systemic service mechanism so that

${ }^{5}$ C.S.T.Kansil, 1989, Pengantar Ilmu Hukum dan Tata Hukum Indonesia, Jakarta : Balai Pustaka, p. 46 
when the officer assigned to handle the request for this Roya unable to attend may be replaced temporarily by another officer, in this case also included if unable to attend is the Head Office of Land.

- Acta notch of Roya consent for the loss of the certificate of mortgage; Unlike the case with land rights certificate, if the certificate is lost or damaged, then the certificate can be issued a replacement for encumbrance certificates are not issued certificate replacement. And therefore to replace the certificate of mortgage made by deed permission or Roya consent Roya security rights as a precondition for Roya to remove the encumbrance for the abolition of the debt (keel). When the consent deed Roya and other requirements listed for the land office, the land office will provide a certificate and book records on land and by Roya letter from the bank. Deed consent alone is not the same Roya letter (letter keel of the bank), Roya letter from a bank letter of request issued by a bank stating that the debtor's debt has been paid off.

Roya consent Deed made by notary it is only a substitute for encumbrance certificates are lost in the process Roya not for execution, so that its position can not be equated with a certificate of mortgages have executorial power because it is not regulated in the legislation or firm rule. The deed of Roya consent is a requirement to carry out orderly land administration. In this case means that the position of Roya consent deed made by the notary is a custom in notarial practice. In the study of customary law can be said to be one of stu formal legal sources.

\subsection{Advice}

Based on some of the conclusions above, here are a few suggestions that author wanted to convey on the issues under review are as follows:

- Land Office should frequently conduct legal education or socialization of Act No. 4 of 1996 on Mortgage, so as to improve knowledge and understanding of the national land law regulations that apply today. Land Office also should provide clear information on the requirements and process the actual Roya.

- Bank as the creditor should explain to potential borrowers who want to do a loan that is about the rights and obligations of the debtor within the specified time period or when the debtor has repaid, to immediately make Roya or deletion.

- For society should if it has been repaid to immediately make Roya or deletion so that the burden of the security rights immediately removed.

\section{References}

[1] Anis Masdurohatun, 2016, Rekonstruksi Parate Eksekusi Hak Tanggungan atas tanah yang berkeadilan. Semarang: Unissula Press.

[2] Boedi Harsono,2002, Himpunan Peraturan-Peraturan Hukum Tanah, Jakarta : Djambatan

[3] Habib Adji, Menjalin Pemikiran-Pemikiran tentang Kenotariatan, Bandung : Citra Aditya Bakti

[4] Habib Adji, 2015. Penafsiran tematik hukum notaris indonesia, Bandung: PT Refika Aditama.

[5] Habib Adjie, 2009, Hukum Notaris Indonesia Tafsir Tematik Terhadap UU No. 30 tahun 2004 Tentang Jabatan Notaris, Bandung : Refika Aditama 